\title{
Grup Kuosien Sebagai Representasi Dari Kode Genetik Standar Berdasarkan Kimia Nukleotida
}

\author{
Isah Aisah ${ }^{1}$, Nurul Ula ${ }^{2}$ \\ 1.)Departemen Matematika,Fakultas MIPA, Universitas Padjadjaran \\ Jl. Raya Bandung Sumedang KM 21 Jatinangor Sumedang 45363 \\ Email: isah.aisah@unpad.ac.id, \\ 2) Mahasiswa S2 Matematika , Institut Teknologi Bandung \\ Jl. Ganesha No. 10 Bandung \\ Email:nurul.ula28@gmail.com
}

\begin{abstract}
ABSTRAK
Kode genetik adalah satu set instruksi untuk mentransfer data genetik yang tersimpan dalam bentuk DNA atau RNA menjadi protein. Kumpulan basa nitrogen dalam rantai RNA dihimpun dan disajikan dalam suatu himpunan $\boldsymbol{N}=\{\mathbf{C}, \mathbf{U}, \mathbf{A}, \mathbf{G}\}$. Pada makalah ini akan ditinjau salah satu grup Kuosien sebagai representasi dari Kode Genetik Standar. Penelitian diawali dengan melakukan pencocokan himpunan $\boldsymbol{N}=\{\boldsymbol{C}, \boldsymbol{U}, \boldsymbol{A}, \boldsymbol{G}\}$ dengan $\mathbb{Z}_{2} \times \mathbb{Z}_{2}=\{(\mathbf{0}, \mathbf{0}),(\mathbf{1}, \mathbf{0}),(\mathbf{0}, \mathbf{1}),(\mathbf{1}, \mathbf{1})\}$. Melalui pencocokan tersebut, maka $N$ memiliki sturktur aljabar sebagai Grup Komutatif terhadap penjumlahan, juga membentuk Grup Kuosien. Terdapat tiga buah grup Kuosien yang dapat dibentuk dari Kode genetik Standar, hal ini tergantung dari sub grup normal sebagai pembentuknya salah satunya berdasarkan Kimia Nukleotida sebagai sub grup normalnya. Selain dari itu himpunan $\boldsymbol{N} \boldsymbol{N} \boldsymbol{N}$ membentuk ruang vektor atas Lapangan Galois atau $G F(4)$.), dengan demikian $\boldsymbol{N N} \subseteq \mathbb{R}^{3}$, sehingga dengan bantuan software Geogebra Kode Genetik Standar dapat disajikan secara geometri sebagai multicube berdimensi tiga.
\end{abstract}

Kata kunci: Kode Genetik Standar, RNA, DNA, Grup Kuosien.

\section{ABSTRACT}

The genetic code is a set of instructions for transferring the stored genetic data in the form of DNA or RNA into proteins. A collection of nitrogenous bases in the RNA chain is presented in a set $N=\{C, U, A, G\}$. This paper will review one of the Qutsien groups as a representation of the Standard Genetic Code. The study begins by matching the set $N=\{C, U, A, G\}$. with $Z \_2 \times Z \_2=\{(0,0),(1,0),(0,1),(1,1)\}$. Through such matching, $N$ has an algebraic structure as a commutative Group of addition, also forming the Quotien Group. There are three Quostien groups that can be formed from the Standard Genetic Code, this depends on the normal subgroup as the one forming based on Nucleotide Chemistry as its normal subgroup. In addition, the NNN set forms a vector space over the Galois Field or GF(4), Thus $N N N \subseteq R^{\wedge} 3$, so that with the help of the Geogebra Software the Standard Genetic Code can be presented geometrically as a three-dimensional multycube.

Keywords: Standard Genetic Code, RNA, DNA, Quotien Group.

\section{Pendahuluan}

DNA berfungsi mengontrol sintesis protein melalui RNA (ribonucleic acid). Suatu molekul RNA terdiri atas satu untai tunggal dan secara kimiawi serupa dengan DNA, hanya saja pada RNA ribosa- lah sebagai gulanya dan basa nitrogen timin (T) diganti dengan urasil (U). Basa RNA disusun pada cetakan DNA maka dalam pengkodean digunakan urasil (U) untuk menentukan kodon dari himpunan basa nukleotida $\{\mathrm{A}, \mathrm{C}, \mathrm{G}, \mathrm{U}\}$ yang diurutkan berdasarkan perbedaan sifat kimiawi nukleotida (purin dan pirimidin) dan ikatan hidrogen basa komplementer (Robersy Sanchez et al., 2007).

Kumpulan basa nitrogen dalam rantai RNA dapat juga disajikan dalam suatu himpunan $N=$ $\{C, \mathrm{U}, \mathrm{A}, \mathrm{G}\}$. Pada artikel (Montano et al, $1996: 119$ ), $N$ kemudian dicocokkan dengan $\mathbb{Z}_{2} \times \mathbb{Z}_{2}=$ $\{(1,1),(1,0),(0,0),(0,1)\}$ dengan dua himpunan yang memuat partisi basa-basa nitrogen berdasarkan 
jenis basa dan ikatan hidrogennya. Selanjutnya dalam artikel (Jose et al, $2006: 217)$ himpunan $N=$ $\{C, U, A, G\}$ dicocokkan dengan $\mathbb{Z}_{2} \times \mathbb{Z}_{2}=\{(0,0),(1,0),(0,1),(1,1)\}$.

Melalui pencocokan tersebut maka $N$ dapat dikaji struktur Aljabarnya serta dapat dilihat representasi dari mutasinya.

\section{Metode Penelitian}

Objek Penelitian ini adalah Kode Genetik Standar. Penelitian dimulai dengan pencocokan Kode Genetik standard $N$ dengan $\mathbb{Z}_{2} \times \mathbb{Z}_{2}$, kemudian diselidiki Struktur Aljabarnya diantaranya sebagai Grup Kuosien, selanjutnya dikelompokkan berdasarkan subgrup Normal yang membentuknya dan akhirnya $N$ direpresentasikan ke dalam Multicube berdimensi tiga.

\section{Hasil dan Pembahasan}

P embahasan akan dimulai dengan struktur aljabar yang sederhana.

Definisi 1 (Herstein, 1964 : 26-27) Suatu himpunan tak kosong $G$ dikatakan membentuk sebuah grup jika pada $G$ didefinisikan suatu operasi biner dinotasikan oleh * , sedemikian sehingga

1) Untuk setiap $a, b, c \in G$ berlaku $a \cdot(b \cdot c)=(a \cdot b) \cdot c$ (hukum asosiatif)

2) Terdapat suatu unsur $e \in G$ sedemikian sehingga $a \cdot e=e \cdot a=a$ untuk setiap $a \in G$ (eksistensi suatu unsur identitas di $G$ )

3) Untuk setiap $a \in G$ terdapat suatu unsur $a^{-1} \in G$ sedemikian sehingga $a \cdot a^{-1}=a^{-1} \cdot a=e$ (eksistensi invers di $G$ )

Definisi 2 (Derek, 2003 : 44) Grup Klein-4 adalah grup dengan order empat dimana setiap elemen adalah invers bagi dirinya sendiri.

Misalkan keempat basa nitrogen pada himpunan $N=\{\mathrm{C}, \mathrm{U}, \mathrm{A}, \mathrm{G}\}$ dilakukan pencocokan $\mathrm{C}=$ $(\overline{0}, \overline{0}), U=(\overline{0}, \overline{1}), A=(\overline{1}, \overline{0})$, dan $G=(\overline{1}, \overline{1})$, maka akan dilihat struktur dari $N$, dengan menggunakan tabel Cayley (tabel 1) berikut :

Tabel 1. Tabel cayley $N$ terhadap penjumlahan

\begin{tabular}{|c|c|c|c|c|}
\hline+ & C & U & A & G \\
\hline C & C & U & A & G \\
\hline U & U & C & G & A \\
\hline A & A & G & C & U \\
\hline G & G & A & U & C \\
\hline
\end{tabular}

Berdasarkan tabel di atas, maka $N$ mempunyai struktur grup Abelian terhadap penjumlahan. Karena setiap unsur mempunyai invers dirinya sendiri maka $N$ membentuk grup Klein-4 terhadap penjumlahan.

Berdasarkan sifat kimia nukleotida, para ilmuwan Biologi mengklasifikasikan $N$ ke dalam tiga himpunan partisi yaitu himpunan $\wp_{1}=\{\{\mathrm{C}, \mathrm{G}\},\{\mathrm{U}, \mathrm{A}\}\}, \wp_{2}=\{\{\mathrm{C}, \mathrm{A}\},\{\mathrm{U}, \mathrm{G}\}\}$ dan $\wp_{3}=\{\{\mathrm{C}, \mathrm{U}\},\{\mathrm{A}, \mathrm{G}\}\}$. Untuk himpunan pertama, $\wp_{1}$ berdasarkan klasifikasi biologi basa kuat nukleotida yang membentuk tiga ikatan hidrogen $\mathrm{S}=\{\mathrm{C}, \mathrm{G}\}$ dan basa lemah nukleotida yang membentuk dua ikatan hidrogen $\mathrm{W}=\{\mathrm{U}, \mathrm{A}\}$. Untuk himpunan kedua, $\wp_{2}$ didasarkan pada klasifikasi kimia nukleotida yaitu amino nukleotida $M=\{C, A\}$ dan keto nukleotida $K=\{U, G\}$. Himpunan ketiga, $\wp_{3}$ didasarkan pada jenis basa nukleotida yaitu pirimidin $\mathrm{Y}=\{\mathrm{C}, \mathrm{U}\}$ dan purin $\mathrm{R}=\{\mathrm{A}, \mathrm{G}\}$. 
Dipandang dari struktur Aljabar yang dipelajari, maka himpunan partisi -partisi tersebut dapat dilihat sebagai Grup Kuosien yang dibentuk dari Grup Klein4, yang dapat dilihat sebagai berikut $(N,+)$ adalah grup Klein-4 yang mempunyai subgrup-subgrup normal yaitu $H_{1}=\{(\overline{0}, \overline{0}),(\overline{0}, \overline{1})\}=\langle(\overline{0}, \overline{1})\rangle, H_{2}=$ $\{(\overline{0}, \overline{0}),(\overline{1}, \overline{0})\}=\langle(\overline{1}, \overline{0})\rangle$, dan $H_{3}=\{(\overline{0}, \overline{0}),(\overline{1}, \overline{1})\}=\langle(\overline{1}, \overline{1})\rangle$.

Sehingga terbentuk tiga grup kuosien, yaitu :

$N / H_{1}=\{\langle(\overline{0}, \overline{1})\rangle+(\overline{0}, \overline{0}),\langle(\overline{0}, \overline{1})\rangle+(\overline{0}, \overline{0})\}=\{\{\mathrm{C}, \mathrm{U}\},\{\mathrm{A}, \mathrm{G}\}\}=\wp_{3}$

$N / H_{2}=\{\langle(\overline{1}, 0)\rangle+(\overline{0}, \overline{0}),\langle(\overline{1}, \overline{0})\rangle+(\overline{0}, 1)\}=\{\{\mathrm{C}, \mathrm{A}\},\{\mathrm{U}, \mathrm{G}\}\}=\wp_{2}$

$N / H_{3}=\{\langle(\overline{1}, \overline{1})\rangle+(\overline{0}, \overline{0}),\langle(\overline{1}, \overline{1})\rangle+(\overline{0}, 1)\}=\{\{\mathrm{C}, \mathrm{G}\},\{\mathrm{U}, \mathrm{A}\}\}=\wp_{1}$

Selain struktur Aljabar dari $N$, maka $N N N=N \mathrm{X} N \mathrm{X} N$ juga mempunyai struktur sebagai Ruang Vektor atas $G F(4)$ sehingga $N N N$ merupakan subruang dari $R^{3}$

Dengan demikian $N N N$ mempunyai basis standar yaitu $\left\{\mathrm{e}_{1}, \mathrm{e}_{2}, \mathrm{e}_{3}, \mathrm{e}_{4}, \mathrm{e}_{5}, \mathrm{e}_{6}\right\}$ dimanae $\mathrm{e}_{1}=\{\overline{1}, \overline{0}, \overline{0}, \overline{0}, \overline{0}, \overline{0}\}$, $\mathrm{e}_{2}=\{\overline{0}, \overline{1}, \overline{0}, \overline{0}, \overline{0}, \overline{0}\}, \mathrm{e}_{3}=\{\overline{0}, \overline{0}, \overline{1}, \overline{0}, \overline{0}, \overline{0}\}, \mathrm{e}_{4}=\{\overline{0}, \overline{0}, \overline{0}, \overline{1}, \overline{0}, \overline{0}\}, \mathrm{e}_{5}=\{\overline{0}, \overline{0}, \overline{0}, \overline{0}, \overline{1}, \overline{0}\}$,

dan $\mathrm{e}_{6}=\{\overline{0}, \overline{0}, \overline{0}, \overline{0}, \overline{0}, \overline{1}\}$. Keenam basis tersebut merupakan basis ortonormal karena mempunyai panjang atau norm 1 dan setiap dua vektor basisnya saling ortogonal, yaitu hasil kali titik antara setiap dua vektor adalah 0 . Sehingga terbentuklah representasi $N N N$ berupa suatu multicube NNN berdimensi tiga yang merupakan gabungan dari 27 kubus unitary dimana berdasarkan definisi Jarak Hamming, panjang atau jarak setiap dua kodon yang terhubung adalah 1.

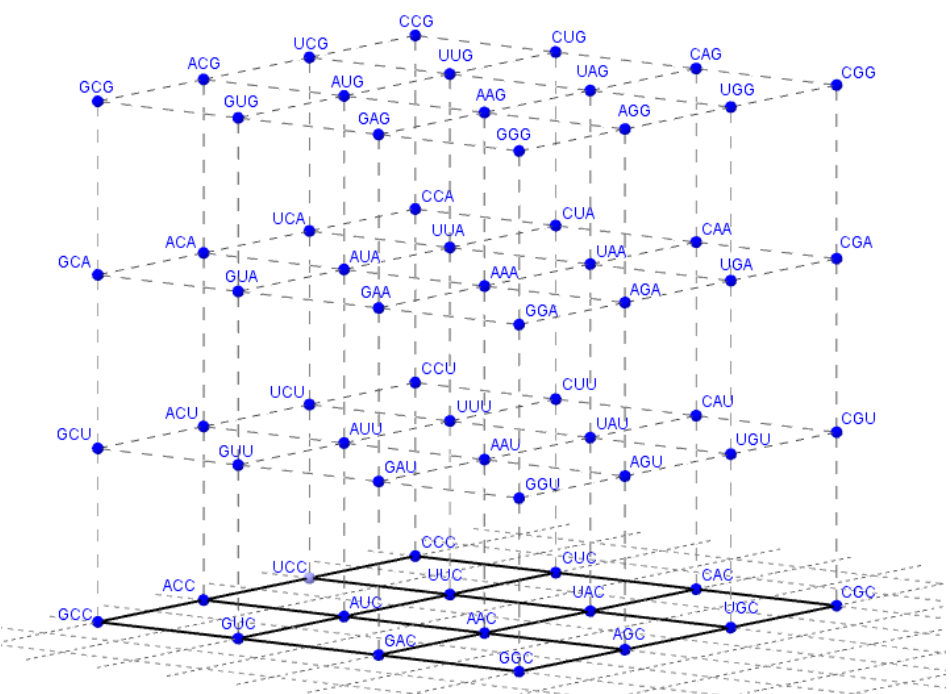

Gambar 1. Representasi Kode Genetik Standar dalam Multicube NNN

Dalam Paper ini Kode Genetik Standar hanya akan direpresentasikan sebagai Grup Kuosien berdasarkan subgrup Normal yang membentuknya yaitu $H_{2}=\{(\overline{0}, \overline{0}),(\overline{1}, \overline{0})\}=\langle(\overline{1}, \overline{0})\rangle$, atau berdasarkan kimia nukleotida.

Sebelum merepresentasikannya ada beberapa translasi yang diperlukan

\subsection{Peran Translasi sebagai Representasi Kode Genetik Standar}

Misalkan $(N,+)$ adalah grup Abelian, himpunan $\mathrm{T}(N)=\left\{\mathrm{T}_{00}, \mathrm{~T}_{01}, \mathrm{~T}_{10}, \mathrm{~T}_{11}\right\}$ merupakan himpunan semua transformasi di $N$ yang kemudian lebih khusus jenis transformasinya adalah translasi. $\mathrm{T}_{00}$ adalah translasi dengan vektor $(\overline{0}, \overline{0}), \mathrm{T}_{01}$ adalah translasi dengan vektor $(\overline{0}, \overline{1}), \mathrm{T}_{10}$ adalah translasi dengan vektor $(\overline{1}, \overline{0})$, dan $\mathrm{T}_{11}$ adalah translasi dengan vektor $(\overline{1}, \overline{1})$.Perhatikan tabel berikut: 
Tabel 2. Tabel Cayley T $(N)$ terhadap komposisi

\begin{tabular}{|c|c|c|c|c|}
\hline$\circ$ & $\mathbf{T}_{\mathbf{0 0}}$ & $\mathbf{T}_{\mathbf{0 1}}$ & $\mathbf{T}_{\mathbf{1 0}}$ & $\mathbf{T}_{\mathbf{1 1}}$ \\
\hline $\mathbf{T}_{\mathbf{0 0}}$ & $\mathrm{T}_{00}$ & $\mathrm{~T}_{01}$ & $\mathrm{~T}_{10}$ & $\mathrm{~T}_{11}$ \\
\hline $\mathbf{T}_{\mathbf{0 1}}$ & $\mathrm{T}_{01}$ & $\mathrm{~T}_{00}$ & $\mathrm{~T}_{11}$ & $\mathrm{~T}_{10}$ \\
\hline $\mathbf{T}_{\mathbf{1 0}}$ & $\mathrm{T}_{10}$ & $\mathrm{~T}_{11}$ & $\mathrm{~T}_{00}$ & $\mathrm{~T}_{01}$ \\
\hline $\mathbf{T}_{\mathbf{1 1}}$ & $\mathrm{T}_{11}$ & $\mathrm{~T}_{10}$ & $\mathrm{~T}_{01}$ & $\mathrm{~T}_{00}$ \\
\hline
\end{tabular}

Dengan memperhatikan Tabel Cayley, maka Himpunan $\mathrm{T}(N)=\left\{\mathrm{T}_{00}, \mathrm{~T}_{01}, \mathrm{~T}_{10}, \mathrm{~T}_{11}\right\}$ merupakan grup.

$(N,+)$ adalah grup Abelian dan $(\mathrm{T}(N), \circ)$ adalah grup.

Perhatikan konstruksi pengaitan berikut.

$$
\begin{aligned}
\mu: N & \rightarrow \mathrm{T}(N) \\
\mathrm{C} & \mapsto \mathrm{T}_{00} \\
\mathrm{U} & \mapsto \mathrm{T}_{01} \\
\mathrm{~A} & \mapsto \mathrm{T}_{10} \\
\mathrm{G} & \mapsto \mathrm{T}_{11}
\end{aligned}
$$

Berdasarkan pengaitan di atas, $\mu$ merupakan pemetaan yang bersifat satu-satu dan pada. Selanjutnya, karena $\mu(\mathrm{X}+\mathrm{Y})=\mu(\mathrm{X})+\mu(\mathrm{Y})$ untuk setiap $\mathrm{X}, \mathrm{Y} \in \mathrm{N}$ maka $\mu$ merupakan homomorfisma grup, sehingga $(\mathrm{N},+) \cong(\mathrm{T}(N), \mathrm{o})$.

Berdasarkan isomorfisma antara $\mathrm{N}$ dengan $\mathrm{T}(\mathrm{N})$, diperoleh empat translasi yang mungkin untuk merepresentasikan mutasi gen adalah $\mathrm{T}_{\mathrm{C}}, \mathrm{T}_{\mathrm{U}}, \mathrm{T}_{\mathrm{A}}$, dan $\mathrm{T}_{\mathrm{G}}$. Translasi $\mathrm{T}_{\mathrm{C}}$ adalah translasi yang mempertahankan struktur dari tiga partisi $\wp_{1}, \wp_{2}$, dan $\wp_{3}$ dari $N$. Tiga translasi non trivial lainnya diilustrasikan dalam diagram berikut.

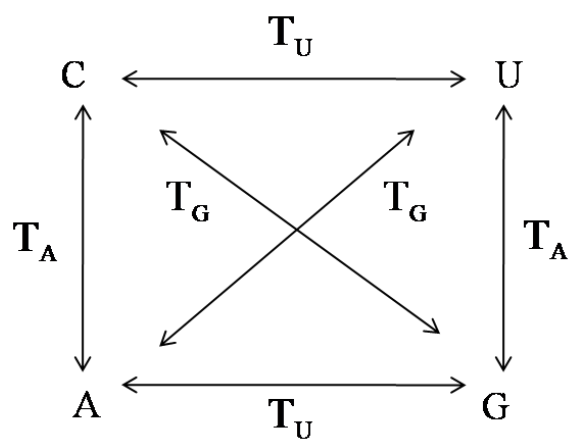

Gambar 2. Translasi Non Trivial $N$

Seperti terlihat dalam diagram, translasi $\mathrm{T}_{\mathrm{U}}$ menunjukkan transisi yang mempertahankan anggota partisi $\wp_{3}$ (klasifikasi pirimidin-purin) namun menukar anggota partisi $\wp_{1}$ dan $\wp_{2}$. Translasi $\mathrm{T}_{\mathrm{A}}$ menunjukkan transversi yang mempertahankan anggota partisi $\wp_{2}$ (klasifikasi amino-keto nukleotida) dan menukar anggota partisi $\wp_{1}$ dan $\wp_{3}$. Translasi $\mathrm{T}_{\mathrm{G}}$ menunjukkan transversi pula, tetapi mempertahankan anggota partisi $\wp_{1}$ (klasifikasi kuat-lemah basa) dan mempertahankan anggota partisi $\wp_{2}$ dan $\wp_{3}$. Dapat disimpulkan bahwa empat translasi mempertahankan himpunan $\left\{\wp_{1}, \wp_{2}, \wp_{3}\right\}$ dari tiga partisi $\wp_{1}, \wp_{2}$ dan $\wp_{3}$. 


\subsection{Representasi Tiga Dimensi Berdasarkan Partisi $\wp_{2}$ (Kimia Nukleotida)}

Pencocokan awal adalah urutan (C, U, A, G) yang akan dikaitkan dengan partisi $\wp_{2}$. Dalam partisi ini matriks yang digunakan adalah matriks $A=\left(\begin{array}{ll}1 & 1 \\ 0 & 1\end{array}\right)$ dan matriks $B=\left(\begin{array}{ll}1 & 0 \\ 1 & 1\end{array}\right)$. Karena kedua matriks tersebut merupakan anggota partisi $\wp_{2}$.

Empat transformasi pertama yang dikenakan pada partisi ini adalah transformasi dengan matriks $B$ yang dikomposisikan dengan setiap translasi $\mathrm{T}_{\mathrm{C}}, \mathrm{T}_{\mathrm{U}}, \mathrm{T}_{\mathrm{A}}$ dan $\mathrm{T}_{\mathrm{G}}$, yaitu $\mathrm{T}_{\mathrm{C}} \circ B=B, \mathrm{~T}_{\mathrm{U}} \circ B, \mathrm{~T}_{\mathrm{A}} \circ B$, dan $\mathrm{T}_{\mathrm{G}} \circ B$.

Matriks $B$ adalah matriks transformasi yang mengubah A menjadi $G$ dan sebaliknya serta mempertahankan $\mathrm{C}$ dan $\mathrm{U}$. Hal ini diperoleh dari perhitungan berikut.

Misalkan $(x, y)=\left(\begin{array}{l}x \\ y\end{array}\right) \in\left(\mathbb{Z}_{2}\right)^{2}$ atau anggota $N$ melalui pencocokan $\left(\mathbb{Z}_{2}\right)^{2}=\{(\overline{0}, \overline{0}),(\overline{0}, \overline{1}),(\overline{1}, \overline{0}),(\overline{1}, \overline{1})\}$ dan $\left(\begin{array}{l}x^{\prime} \\ y^{\prime}\end{array}\right)$ adalah hasil transformasi atau bayangan dari $\left(\begin{array}{l}x \\ y\end{array}\right)$ dengan matriks $B$, sehingga

$$
\left(\begin{array}{l}
x^{\prime} \\
y^{\prime}
\end{array}\right)=B\left(\begin{array}{l}
x \\
y
\end{array}\right)=\left(\begin{array}{ll}
1 & 0 \\
1 & 1
\end{array}\right)\left(\begin{array}{l}
x \\
y
\end{array}\right)=\left(\begin{array}{c}
x \\
x+y
\end{array}\right)
$$

Jadi, pengurutan (C, U, A, G) jika dikenakan matriks transformasi $B$ akan menjadi pengurutan (C, U, G, A). Selanjutnya akan ditinjau Transformasi dengan matriks $A_{21}$

Matriks transformasi yang digunakan adalah $A_{21}$ yaitu

$$
A_{21}=\left[\begin{array}{ll}
\overline{1} & \overline{0} \\
\overline{1} & \overline{1}
\end{array}\right]
$$

Misalkan, pilih kodon CGU, Maka dengan matriks transformasi $A_{21}$, bayangan atau hasil transformasinya diperoleh melalui perhitungan berikut :

a) Untuk basa $\mathrm{C}$ urutan pertama pada urutan (C, G, U)

$$
\left[\begin{array}{l}
x^{\prime} \\
y^{\prime}
\end{array}\right]=\left[\begin{array}{ll}
\overline{1} & \overline{0} \\
\overline{1} & \overline{1}
\end{array}\right]\left[\begin{array}{l}
\overline{0} \\
\overline{0}
\end{array}\right]=\left[\begin{array}{l}
\overline{0} \\
\overline{0}
\end{array}\right]=\mathrm{C}
$$

Jadi, bayangan $\mathrm{C}=\mathrm{C}$.

b) Untuk basa $\mathrm{G}$ urutan kedua pada urutan (C, G, U)

$\left[\begin{array}{l}x^{\prime} \\ y^{\prime}\end{array}\right]=\left[\begin{array}{ll}\overline{1} & \overline{0} \\ \overline{1} & \overline{1}\end{array}\right]\left[\begin{array}{l}\overline{1} \\ \overline{1}\end{array}\right]=\left[\begin{array}{l}\overline{1} \\ \overline{0}\end{array}\right]=\mathrm{A}$

Jadi, bayangan $\mathrm{G}=\mathrm{A}$.

c) Untuk basa U urutan ketiga pada urutan (C, G, U)

$\left[\begin{array}{l}x^{\prime} \\ y^{\prime}\end{array}\right]=\left[\begin{array}{ll}\overline{1} & \overline{0} \\ \overline{1} & \overline{1}\end{array}\right]\left[\begin{array}{l}\overline{0} \\ \overline{1}\end{array}\right]=\left[\begin{array}{l}\overline{0} \\ \overline{1}\end{array}\right]=\mathrm{U}$

Jadi, bayangan $\mathrm{U}=\mathrm{U}$.

Jadi, dari perhitungan di atas diperoleh $(\mathrm{C}, \mathrm{G}, \mathrm{U}, \mathrm{A}) \stackrel{A_{21}}{\longrightarrow}(\mathrm{C}, \mathrm{A}, \mathrm{U}, \mathrm{G})$.

Perhitungan yang sama dilakukan untuk 63 kodon lainnya.

Selanjutnya dengan perhitungan yang sama dan berdasarkan transformasi-transformasi $T_{G} \circ A_{21}, T_{U} \circ A_{12}{ }^{\circ} A_{21}$, dan $T_{G} \circ A_{12}{ }^{\circ} A_{21}$, mengubah pengurutan $(C, U, A, G)$ menjadi $(G, A, C, U)$, $(U, A, C, G),(G, C, A, U)$.

Dengan demikian terdapat 8 representasi yang berbeda dari Kode Genetik Standar berdasarkan Grup Kuosien yang dibentuk oleh subgroup Normal $H_{2}$. atau berdasarkan Kimia Nukleotida. Seluruh representasi digambar dengan menggunakan software Geogebra. Berikut akan ditampilkan 4 representasi berdasarkan macam-macam matriks transformasi, dengan pengurutan awal dimulai dari (C,U,A,G). 


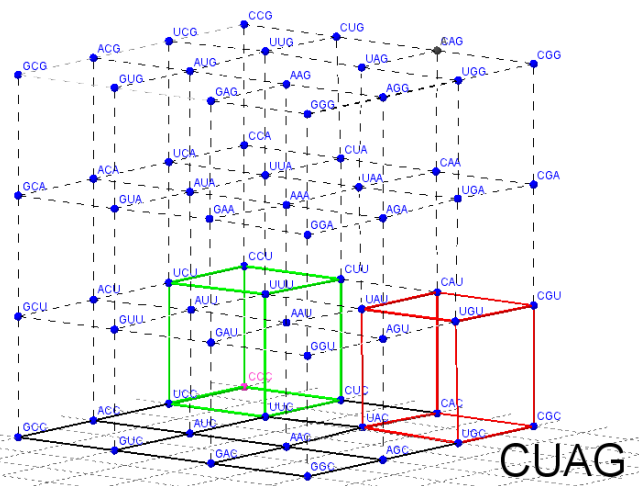

Gambar 3. (C,U,A,G)

Dengan menggunakan Transformasi matriks $A_{21}$ Representasi di atas menjadi gambar 4 .

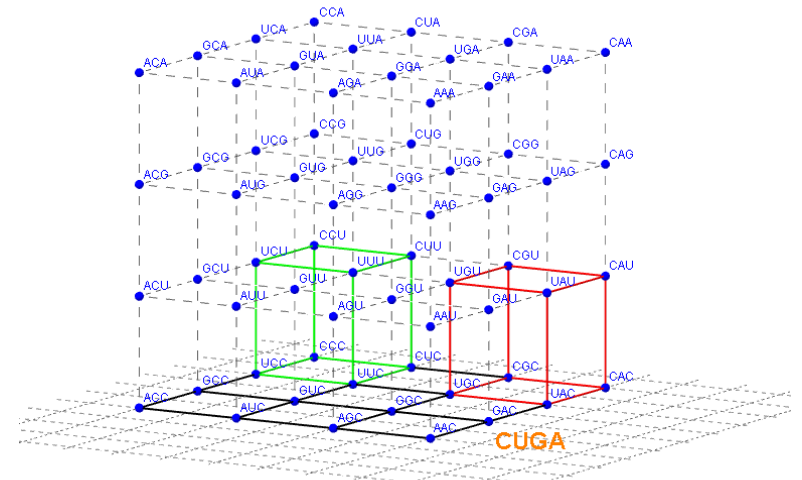

Gambar 4. (C,U,G,A)

Dengan menggunakan Transformasi matriks $T_{G} \circ A_{21}$, gambar 3. menjadi gambar 5 .

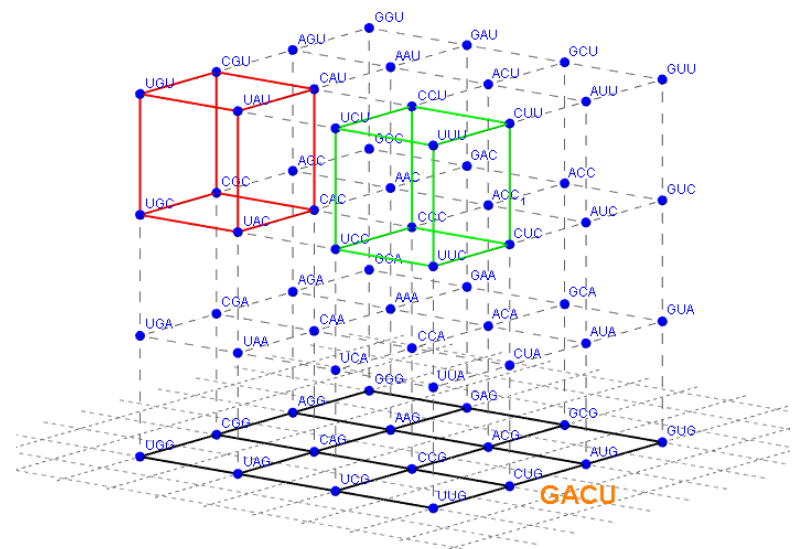

Gambar 5. (G,A,C,U)

Dengan menggunakan Transformasi matriks $T_{U} \circ A_{12}{ }^{\circ} A_{21}$ gambar 3.3 menjadi gambar 3.6 


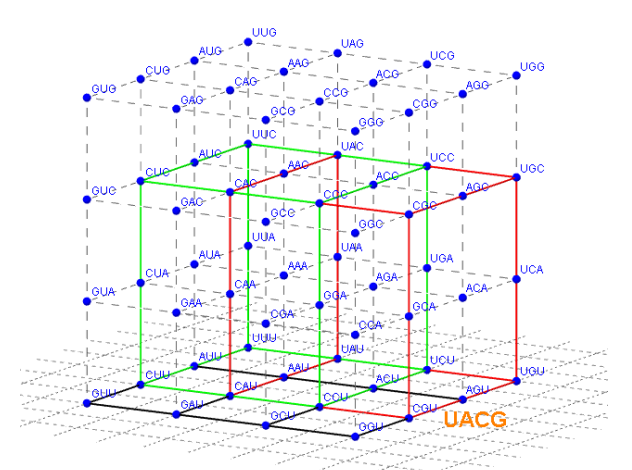

Gambar 6. (U,A,C,G)

Dengan menggunakan Transformasi matriks $T_{G} \circ A_{12}{ }^{\circ} A_{21}$ gambar 3 menjadi gambar 7 .

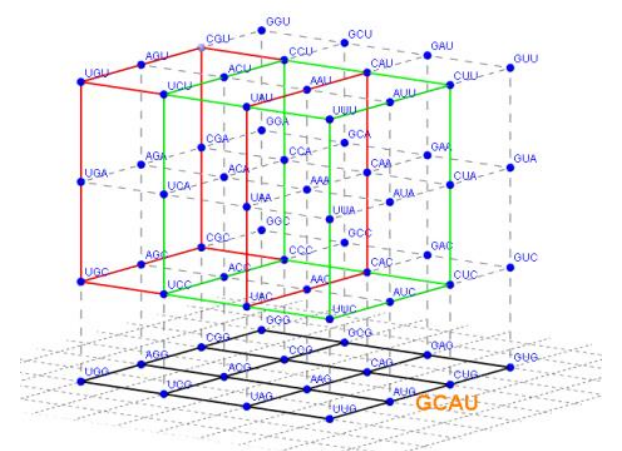

Gambar 7. (G,C,A,U)

\section{Simpulan}

Kode Genetik Standar mempunyai struktur aljabar sebagai Grup, Grup Klein 4, Grup Kuosien. Terdapat 3 grup Kuosien berdasarkan subgrup normal yang membentuknya,diantaranya berdasarkan sub grup normal Kimia Nukleotida. Dengan menggunakan transformasi tertentu dan bantuan software Geogebra, Kode Genetik Standar dapat direpresentasikan secara geometri ke dalam multicube dimensi tiga.

\section{Daftar Pustaka}

1. Campbell et all 2008. Biologi ,Edisi kedelapan Jilid 1 , terjemahan oleh Damang Tyas Wulandari Erlangga, Jakarta, 2010

2. Herstein,I.N., Topics in Algebra, Ginn and Company : London, 1995

3. Jimenez-Montano, Miguel A. The Hypercube Structure of The Genetic CodeExplains Conservative and Non Conservative Aminoacid Substitutions in Vivo and in Vitro, BioSystems, 1996(39) : 117-125

4. Jose.Marco V et al. Genetic Hotels for the standard genetic Code : Evolutionary Analysis Based Upon Novel Three-Dimensional Algebraic Models. Bull.Math.Biol,2010 (73) : 1443-1476

5. Jose.Marco V et al. The 24 Possible Algeraic Representations of Standard Genetic Code in Six or in Three Dimensions. Advanced Studies in Biology, 2012,4(3) : 119-152 